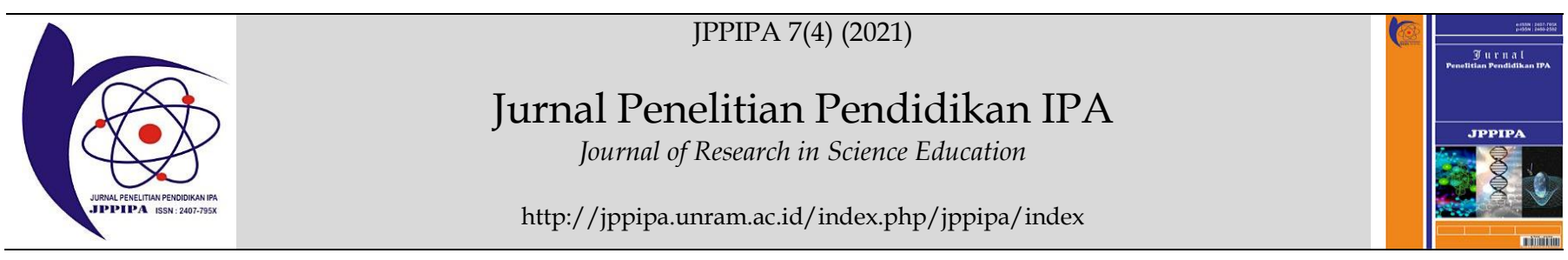

\title{
Development of E-learning Module based on Multiple Representation Integrated with GeoGebra
}

\author{
Rizki Hananan Sari. ${ }^{1 *}$, A. Halim², Yusrizal $^{2}$ \\ ${ }^{1}$ Science Education Study Program Postgraduate Program at Syiah Kuala University, Banda Aceh, Indonesia \\ ${ }^{2}$ Physics Study Program, FKIP, Syiah Kuala University, Banda Aceh, Indonesia
}

DOI: $10.29303 /$ jppipa.v7i4.856

\section{Article Info}

Received: August 3rd, 2021

Revised: October $10^{\text {th }}, 2021$

Accepted: October 17th, 2021

\begin{abstract}
The purpose of this research is to know the feasibility, practicality, and effectiveness of e-learning modules based on multiple representations integrated with Geogebra at students of class X semester two at Aceh Seulimuem Senior High School no 1. This study uses Research and Development Method with the ADDIE model. The result for feasibility is very feasible to use with the average validation assessment in the amount of $82.95 \%$. At the same time, the practicality from students responses got average percentage is $87.80 \%$ classified within the very practical criteria. The effectiveness shows from the Mann Whitney $U$ test shows that there is a difference in the average value of pre-test and post-test participants learners, which can be summarized that the module is effective to be applied.
\end{abstract}

Keywords: Multiple Representation; GeoGebra; E-Learning; Module.

Citation: Sari, R., Halim, A., \& Yusrizal, Y. (2021). Development of E-learning Module based on Multiple Representation Integrated with GeoGebra. Jurnal Penelitian Pendidikan IPA, 7(4), doi:https://doi.org/10.29303/jppipa.v7i4.856

\section{Introduction}

The covid-19 pandemic is a worldwide disaster that impacts too many aspects of real life. One of them is education. The education minister said that pandemics cause hundreds of thousands of schools to be closed, so new normal life should be applied in the teaching and learning process (Duraku \& Hoxha, 2020). This process is required students and teachers to master technology well. One technology used is E-Learning, which provides ease in the learning process (Tadesse \& Muluye, 2020).

Multiple representations are one approach that is useful in the learning process for many students with different kinds of learning style because it provides many representations such as us verbal, graph, pictures, and mathematic (Widakdo, 2017). Because so many materials are easily attached in e-learning, it allows multiple representation approaches to apply in the learning process. Software that can be used in multiple representations is GeoGebra, where its simulated ion can provide graph and mathematical representation. This research aims to know the appropriateness, practicality, and effectiveness of elearning modules based on multiple representations integrated with GeoGebra.

Each student has a different interpretation when solving the concepts in science learning as a different ability of the internal interpretation of student (Dimas et al. 2017). Their prior knowledge or experience supports the ability of the student to interpret a concept. Various cases and abstract concepts in science make it difficult for students to interpret when they only use the internal interpretation emerging from their minds. The internal interpretation skills must be supported by the ability of external representation related to the real world or the surrounding environment to facilitate the students in gaining the knowledge through the thinking process and consider the information they will have (Treagust et al., 2017). Multiple representation functions are; to provide representations that contain complementary 
information or help complete cognitive processes, to limit the possibility of misinterpretation in using another representation, and to encourage students to build an in-depth understanding of the situation (Opfermann et al., 2017)

GeoGebra is the name of a software (software) installed on the computer to solve math problems. Application (program) combines geometry, algebra, and calculus (Septian et al., 2020). GeoGebra is a computer application program used to solve mathematical problems software developed by Markus Hovenwarter at Florida Atlantic University for teaching and learning mathematics in public schools (Rosa, 2017).

IGI (International GeoGebra Institute) is the nonprofit organization behind the development of GeoGebra mathematical software (Hohenwarter et al., 2009). At IGI, mathematics teachers and researchers from around the world work together to promote the teaching of mathematics by coordinating conference activities, coaching as follows: (1) Developing and implementing new features of GeoGebra software; (2) Develop an online support system for teachers; (3) Evaluate and enhance professional development activities and mathematical instructional materials. The software is perfect for use in the process of learning mathematics, as GeoGebra displays three different perspectives on mathematical objects such as graphics, numerical algebra, and Spreadsheets (Zilinskiene \& Demirbilek, 2015). This allows us to display mathematical objects in three different representations: graphically (point, the graph of a function), algebra (the coordinates of points, equations), and spreadsheet cells. In use, GeoGebra can run on Windows family of operating systems, Mac OS X, and Linux is easy to use because it can be executed with basic commands such as scrolling, zooming, delete, and could use a hotkey like in Windows (Singh, 2019).

By using this GeoGebra software program, a variety of mathematical problems can be solved. Users will get a better visualization and potentially easier to understand to get answers to various problems of mathematics. GeoGebra was published with the slogan "GeoGebra-Dynamic Mathematics for Everyone", the developer claimed GeoGebra as a dynamic geometry application because it can carry out the construction of points, vectors, segments, lines, conic sections, as well as functions, and change the outcome of further construction. On the other hand, GeoGebra also has the ability as the geometry calculator that can handle variables in the form of numbers, vectors, points, finds derivatives and integrals of a function, and offers direct commands like Root or Extremes. (Rosa, 2017)

E-learning is the use of electronic devices and Internet technologies to deliver a variety of solutions to enable learning and improve performance. E-learning courses are stand-alone interactive learning materials that correspond to one or more learning objectives by providing explanations, examples, interactivity, questions and feedback, glossaries, etc., in order to make learners self-sufficient in learning new concepts and skills. (Al-Atabi \& Akram, 2020). They can combine several types of media, including text, images, animations, audio, and video. E-learning courses can include one or more e-learning lessons, whose duration should be limited to a maximum of about 30 minutes of learning time. An e-learning lesson can have a linear sequence, where content is presented in a predefined order, or it can take a branching approach, where learners follow different paths according to their choices (FAO, 2021). E-module is a form of presentation of material to learn independently which is compiled by systematically to the unit of learning, which is presented in the format of electronics, where every activity of learning in it is connected with a link (link) as navigation which makes the participant students become more interactive with the program, include presentation of video tutorials, animations, and audio to enrich the learning experience (Mulyadi et al., 2019).

\section{Method}

The method used in this research is Research and Development $(R \& D)$. There are five stages in the model ADDIE: Analyze, Design, Development, Implementation, and Evaluation. The implementation of this module on impulse and momentum material for students of class $X$ semester two at Aceh Seulimuem Senior High School no 1 of the academic year 2020/2021. Instruments that are used to collect data on research can be classified into three kinds of instruments.

\section{Validation Sheet}

The validation sheet is used to collect to measure the validity of the learning module. This research questionnaire will be addressed to expert lecturers. This questionnaire determines whether teaching materials are suitable for use without revision, with revisions, or not suitable to apply. This questionnaire is in the form of a rating-score (leveled scale) with four categories of assessment from the highest, and there are: $4,3,2,1$, which calculated by percentage formula:

$$
P=\frac{f}{n} x 100
$$

\section{Information:}

p: percentage

$\mathrm{f}$ : number of the respondent of each item

$\mathrm{n}$ : the number of ideal values 
Tabel 1. Feasible Criteria

\begin{tabular}{lll}
\hline No & Criteria & Interval (\%) \\
\hline 1 & Very worth & $81 \leq \mathrm{P} \leq 100$ \\
2 & Worth & $61 \leq \mathrm{P} \leq 80$ \\
3 & Decent enough & $41 \leq \mathrm{P} \leq 60$ \\
4 & Not feasible & $21 \leq \mathrm{P} \leq 40$ \\
5 & Very Unworthy & $0 \leq \mathrm{P} \leq 20$ \\
\hline
\end{tabular}

\section{Student response questionnaire}

Student response questionnaires were used to measure the practicality aspect. This questionnaire aims to obtain data on students' opinions about the learning process by using the module. This questionnaire is in the form of a Likert scale with four assessment categories, namely: strongly agree (score 4), agree (score 3), disagree (score 2), strongly disagree (score 1 ). Which also calculated by percentage formula:

$P=\frac{f}{n} \times 100$

Information:

p: percentage

$\mathrm{f}$ : number of the respondent of each item

$\mathrm{n}$ : the number of ideal values

Tabel 2. Practicality Category

\begin{tabular}{lll}
\hline No & Category & Percentage (\%) \\
\hline 1 & Very practice & $81 \leq \mathrm{P} \leq 100$ \\
2 & Practice & $61 \leq \mathrm{P} \leq 80$ \\
3 & Practice enough & $41 \leq \mathrm{P} \leq 60$ \\
4 & Unpractice & $21 \leq \mathrm{P} \leq 40$ \\
5 & Very unpractice & $0 \leq \mathrm{P} \leq 20$ \\
\hline
\end{tabular}

\section{Student Learning Outcome Test}

The student learning outcomes test is used to measure the effectiveness aspect. This instrument obtains data on learning outcomes by using an elearning module based on multiple representations. The data are analyzed by using the Mann Whitney U ttest.

\section{Result and Discussion}

The results were obtained from the stages of the model ADDIE, which is explained as follow:

\section{Identification Results}

Researchers found the result of observations that students' motivation and understanding of the concept are still low. When learning online, some learners do not collect duties given by teachers at each meeting, the rest of collecting duties, but still do not understand the material given online. So also the case when offline learning, some participants learners look passive and less participative when learning in class. They only hear when the teacher explains in front of the classroom. During the process of question and answer, there are some participants learners are active. However, there is also a look of curiosity wanted to ask but did not want to because they hesitated to. Besides that, the participant students also still think that physics is the most difficult subject.

\section{Design Results}

The design result of this research is an e-learning module based on multiple representations integrated with GeoGebra. Steps for developing a design to adjust the standard of competence and basic competence. Preparation of design module e-learning is designed in accordance with the model of multiple representations as well as the stages of development, and the materials are going to study that momentum and impulse. The Elearning module uses google classroom as the Learning Management System. It is consists of menu forums, tasks, members, and value.

\section{Development Results}

The process of development of the module is through the stages of validation and process assessment design. Process validation and assessment of design is done by asking the opinion of lecturers

\section{1) Material Expert Validation}

Eligibility criteria are obtained from the percentage results, namely the number of respondents' answers per aspect divided by the number of ideal values per aspect multiplied by $100 \%$. The average percentage is obtained from the total percentage of all aspects divided by the number of aspects. The following is the assessment of the material expert validator.

Table 3. Recapitulation of Material Expert Validation.

\begin{tabular}{lllll}
\hline Aspect & $\left(\sum \mathrm{x}\right)$ & $\left(\sum \mathrm{x}_{1}\right)$ & Percentage & Criteria \\
\hline Content feasibility & 117 & 136 & $86,02 \%$ & Very worthy \\
Presenation & 84 & 104 & $77,88 \%$ & Worthy \\
Language & 62 & 72 & $86,11 \%$ & Very worthy \\
$\begin{array}{l}\text { Sum } \\
\text { Average }\end{array}$ & 263 & 312 & & \\
\hline
\end{tabular}

The result was achieved on average very feasible with a percentage of $83.36 \%$. As for details of the percentage, the aspect contents feasible amounted to $86.02 \%$ with the criteria of very decent, aspects of the presentation by $77.88 \%$ with the criteria of interpretation feasible, aspects of language by $86.11 \%$ with the criteria of very decent.

\section{2) Media Expert Validation}

Assessment on media expert validation is almost the same as assessment on material expert. The average 
percentage is obtained from the total percentage of all aspects divided by the number of aspects so that the interpretation criteria that have been determined are obtained. After that, it is adjusted to the assessment and determination of interpretation criteria on media expert validation. The assessment of the media expert validator before the revision can be seen in the following table:

Table 4. Recapitulation of Media Expert Validation

\begin{tabular}{lllll}
\hline Aspect & $\left(\sum x\right)$ & $\left(\sum \times 1\right)$ & Persentase & Criteria \\
\hline Media feasible & 55 & 64 & $85,93 \%$ & Very worthy \\
Language feasible & 76 & 96 & $79,16 \%$ & Worthy \\
$\begin{array}{l}\text { Total } \\
\text { Average }\end{array}$ & 131 & 158 & & \\
\hline
\end{tabular}

The result shows that the average is very feasible, with a percentage of $82.54 \%$. As for details of the percentage, the aspect media feasible amounted to $85.93 \%$ with the criteria of very decent, aspects of the feasibility of the language by $79.16 \%$ with the criteria of interpretation worthy.

\section{3) Results of Testing}

The result is to determine the module's practicality by giving the questionnaire responses of participants learners using the application google form.

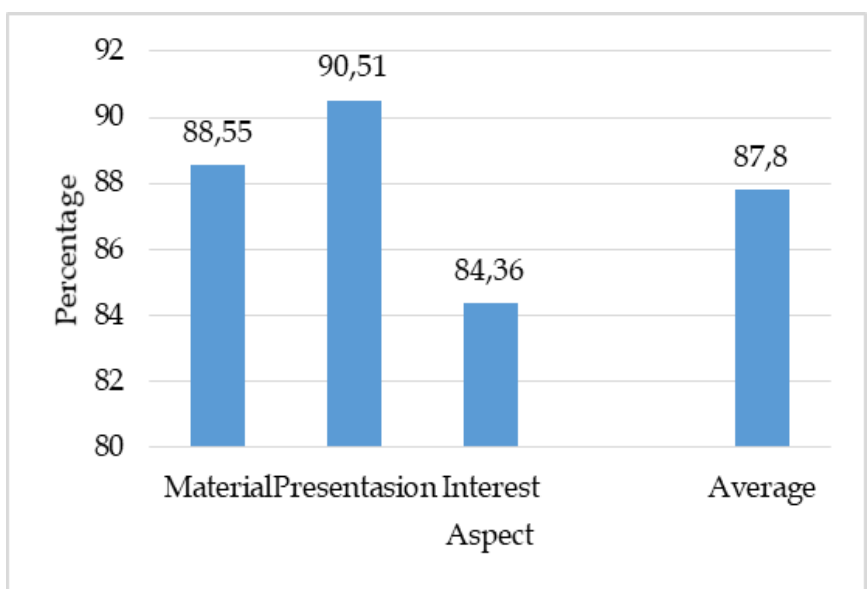

Figure 1. Module Practicality

Figure 1 shows the result of the questionnaire of module practicality. The aspect of the material percentage who achieved was $88.54 \%$, the presentation aspect reached $90.51 \%$, and aspects of interest reached $84.35 \%$. Overall, every aspect of getting the interpretation criteria is very practical. From the results of recapitulation of the results of the response pe and students conclude that the module e-learning that is developed reaches a percentage average of $87.80 \%$ with criteria "very practical."

\section{Evaluation Results}

The results of the evaluation in the form of pretest and post-test to the students to determine the increase in understanding of the concept after the given module with the purpose to determine the effectiveness of the product. Based on the normality test results, it was concluded that the data were not normally distributed, so the data were tested using nonparametric statistics using the Mann Whitneyy U test, analysed by SPSS software. The Asymp value was obtained Sig (2-tailed) is 0.000 is smaller than the value of the probability of 0.05 , so it is received Ha. It means that there are differences in the average score of pre-test and post-test participant students were given the module. So it can be concluded that the E-learning module based on multiple representations integrated with GeoGebra effectively improves the understanding of class X students of SMA Negeri 1 Seulimeum.

The results of the study showed that the learning-based multiple representations effectively against the understanding of participants learners. Among the results of the research of Hasbullah et al. (2018), examined the ability to understand the representation of students on the material motion straight, which increased after being taught by a model of learning multiple representations. The study further, which also supports is the research of Mirzatullah et al. (2020), which compares learning to use the module multiple representations of the book text, shows that there are students who are taught by module multiple representations has the power to remember the more robust compared with students who are taught by the book text. Research is done by Wiyarsi et al. (2018) focused on analyzing students' creative thinking skills in implementing multiple representation approach on 'rate of reaction' topic showed that the CAM-MRA facilitated the students' creative thinking skills of 'rate of reaction.' However, the students still had difficulty showing the microscopic representation.

\section{Conclusion}

E-learning modules based on multiple representations are integrated with GeoGebra that developed is very feasible to use with the average validation assessment in the amount of $82.95 \%$, while the practicality form students responses classified within the criteria of very practical with average percentage is $87.80 \%$. The effectiveness shows from the statistics calculation shows that there is a difference in the average value of pre-test and post-test participants learners, which can be concluded that the module is effective to be applied. 


\section{References}

Dimas, A., Suparmi, A., Sarwanto, S., \& Nugraha, D. A. (2018). Analysis multiple representation skills of high school students on simple harmonic motion. AIP Conference Proceedings, 2014(September 2018). https://doi.org/10.1063/1.5054535

Duraku, Z. H., \& Hoxha, L. (2020). The impact of COVID-19 on education and on the well-being of teachers, parents, and students: Challenges related to remote (online) learning and opportunities for advancing the quality of education. 1-28.

FAO. (2021). E-learning methodologies and good practices: A guide for designing and delivering e-learning solutions from the FAO elearning Academy, second edition. Rome. doi: https://doi.org/10.4060/i2516e

Hasbullah., Halim, A., \& Yusrizal. (2018) Penerapan Pendekatan Multi Representasi Terhadap Pemahaman Konsep Gerak Lurus. (JIPI) Jurnal IPA dan Pembelajaran IPA, 2(2). 69-74. doi: https://doi.org/10.24815/jipi.v2i2.11621 [Indonesian]

Hohenwarter, M., Jarvis, D., \& Lavicza, Z. (2009). Linking geometry, algebra, and mathematics teachers: GeoGebra software and the establishment of the International GeoGebra Institute. International Journal for Technology in Mathematics Education, 16, 83-87

Mirzatullah, A. Halim, \& Hamid, A. (2020) The Comparison of Multi Representation Based Module and Text Books on Black Principle Material in Physics Learning Reviewed from Student Retention. Asian Journal of Science Education, 2(1), 33-40. doi: https://doi.org/10.24815/ajse.v2i1.14796

Mulyadi, M., Atmazaki, A., \& R, S. (2019, January 1). The Development of Interactive Multimedia EModule on Indonesia Language Course. Conference: Proceedings of the 1st International Conference on Innovation in Education (ICoIE 2018). https://doi.org/10.2991/icoie-18.2019.65

Opfermann, M., Schmeck, A., \& Fischer H.E. (2017) Multiple Representations in Physics and Science Education - Why Should We Use Them? In: Treagust D., Duit R., Fischer H. (eds) Multiple Representations in Physics Education. Models and Modeling in Science Education, vol 10. Springer, Cham. https://doi.org/10.1007/978-3-319-589145_1

Rosa, A. T. R. (2017, April 1). Implementation of Media Software Geogebra Develpoment in Mathematics Learning (R\&D Study in BAndung SMK). 12th ADRI International Multidiciplinary ConferenceAt: Universitas Pakuan, Bogor-Indonesia
Rosa, Ade Tuti R. (2017). Implementation of Media Software Geogebra Develpoment in Mathematics Learning (RED Study in BAndung SMK). Conference Paper. ResearchGate. [Indonesian]

Septian, A., Inayah, S., Suwarman, R. F., \& Nugraha, R. (2020). GeoGebra-Assisted Problem Based Learning to Improve Mathematical Problem Solving Ability. Advances in Social Science, Education and Humanities Research, 467(Semantik), 67-71.

https://doi.org/10.2991/assehr.k.200827.119

Singh, L. (2019). Impact of Using Geogebra Software on Students' Achievement in Geometry: A Study at Secondary Level. Retrieved from: https://www.researchgate.net/...Secondary_Lev $\underline{\mathrm{el}}$

Tadesse, S., \& Muluye, W. (2020). The Impact of COVID-19 Pandemic on Education System in Developing Countries: A Review. Open Journal of Social Sciences, 08(10), 159-170. https://doi.org/10.4236/jss.2020.810011.

Treagust, D. F., Duit, R., \& Fischer, H. E. (2017). Multiple representations in physics education (Vol. 10). Springer.

Widakdo, W. A. (2017). Mathematical Representation Ability by Using Project Based Learning on the Topic of Statistics. Journal of Physics: Conference Series, 895, 12055. https://doi.org/10.1088/1742$6596 / 895 / 1 / 012055$

Wiyarsi, A., Sutrisno, H., \& Rohaeti, E. (2018). The effect of multiple representation approach on students' creative thinking skills: A case of 'Rate of Reaction' topic. Journal of Physics: Conference Series, 1097, 12054. https://doi.org/10.1088/17426596/1097/1/012054

Zilinskiene, I., \& Demirbilek, M. (2015). Use of GeoGebra in Primary Math Education in Lithuania: An Exploratory Study from Teachers' Perspective. Informatics in Education, 2015, 127142. https://doi.org/10.15388/infedu.2015.08 